\title{
KAJIAN KANTIN JUJUR DALAM RANGKA PENINGKATAN PENDIDIKAN KARAKTER DI TINGKAT SEKOLAH DASAR UNTUK MEWUJUDKAN SISWA YANG KREATIF (STUDI KASUS DI SDN PANGGUNGREJO 04 KEPANJEN)
}

\author{
Yulianti
}

\begin{abstract}
The era of reform has had an impact in the world of education, the number of students or elementary school age children to lie in his behavior. This is not consistent with the objectives of the national education UUSPN No. 202003 . The existence of this law to provide insight to the institution of formal, informal and non-formal, in order to carry out the process of education and learning in shaping the character of the nation and state of Indonesia. SDN Panggungrejo 4 is one character education program honest. This study used a qualitative research approach. Data collection techniques used include : interviews, observation, documentation. Data collected in check by using the technique of triangulation. The purpose of the study was ( 1$)$ to describe the strategy of implementation of character education in SDN Panggungrejo 4, ( 2 ) describe a model implementation honest cafeteria, ( 3 ) describe the implementation of the management of the canteen honest. To answer the above problems the researcher uses descriptive qualitative data analysis and the results of this study will be uploaded to the Air ISSN journal as outputs.
\end{abstract}

\begin{abstract}
Abstrak : Era reformasi telah membawa dampak dalam dunia pendidikan, banyaknya siswa atau anak-anak usia SD melakukan kebohongan dalam tingkah lakunya. Hal ini tidak sesuai dengan tujuan pendidikan nasional yaitu UUSPN No. 20, Tahun 2003. Adanya undang-undang ini untuk memberikan wawasan kepada lembaga pendidikan baik formal, informal maupun non formal, agar melaksanakan proses pendidikan dan pembelajaran dalam membentuk karakter bangsa dan negara Indonesia. SDN Panggungrejo 4menerapkan pendidikan karakter salah satunya programnya pelaksanaankantin jujur. Penelitian ini menggunakan pendekatan penelitian kualitatif. Teknik pengumpulan data yang digunakan meliputi: Wawancara, Observasi, dokumentasi. Data yang terkumpul di cek dengan menggunakan teknik triangulasi. Adapun tujuan penelitian adalah (1) mendeskripsikan strategi pelaksanaan pendidikan karakter di SDN Panggungrejo 4, (2) mendeskripsikan model pelaksanaan kantin jujur, (3) mendeskripsikan manajemen pelaksanaan kantin jujur. Untuk menjawab permasalahan di atas peneliti menggunakan analisis data deskriptif kualitatif dan hasil penelitian ini akan diunggah ke jurnal ber ISSN sebagai luaran.
\end{abstract}

Kata Kunci: kantin jujur, pendidikan karakter, siswa yang kreatif

\section{A. PENDAHULUAN}

Menyikapi perkembangan actual terhadap munculnya perilaku destruktif, anarkis dan radikalis, pendidikan memiliki peran dan tanggung jawab besar. Oleh karena itu, diperlukan kemauan untuk mengajak para pemangku kepentingan pendidikan, terutama Kepala Sekolah dan Guru untuk memberikan perhatian dan pendampingan lebih besar kepada peserta didik dalam membentuk dan menumbuhkan pola pikir dan perilaku yang berbasis kasih sayang, toleran terhadap realitas keanekaragaman yang dibernarkan oleh peraturan dan perundangan. Disini sekolah merupakan lembaga pendidikan yang ikut bertanggung jawab da- 
lam upaya membentuk pribadi positif. Terutama di tingkat sekolah dasar (SD) perilaku-perilaku positif perlu dibentuk sejak awal sebagai pondasi dalam membangun karakter bangsa.

Salah satu karakter bangsa yang perlu dikembangkan adalah kejujuran. Kejujuran merupakan sifat terpuji yang harus dimiliki setiap orang. Sifat kejujuran perlu ditanamkan dalam diri seseorang sedini mungkin, karena kejujuran merupakan tanggung jawab moral seseorang terhadap nilai-nilai dan norma-norma agama dan masyarakat. Penanaman sifat kejujuran di sekolah harus ditekankan sebab tujuan pendidikan tidak hanya berujung pada peningkatan kecerdasan intelegensi semata, namun juga harus diiringi dengan peningkatan kualitas budi pekerti. Penanaman kejujuran melibatkan titiga pilar utama, yakni keluarga, sekolah, dan masyarakat. Sekolah merupakan lembaga pendidikan yang ikut bertanggung jawab dalam upaya membentuk perilaku positif.

Dari hasil wawancara dengan Kepala Sekolah dan Guru SDN Panggungrejo 04 Kepanjen beliau menyampaikan bahwa di masyarakat kita terjadi pergeseran nilai yang tidak hanya mudah marah tetapi juga banyak ditemui ketidakjujuran termasuk banyak contoh perilaku pimpinan di negara ini tidak jujur yang ditunjukkan banyaknya pejabat yang korupsi. Kepala Sekolah dan Guru SDN Panggungrejo 04 Kepanjen selalu menekankan penanaman karakter yang baik salah satunya pembentukan perilaku siswa dengan sifat jujur.

Hasil Observasi tanggal 15 Januari 2013, SDN Panggungrejo 04 Jl. PanjiKepanjen merupakan salah satu Sekolah Dasar Negeri di kabupaten Malang yang menerapkan kurikulum pendidikan karakter yang bersumber dari kurikulum nasional dibawah naungan Departemen Pendidikan Nasional. Hal ini terlihat ada- anya "kantin jujur" di SDN Panggungrejo 04 Kepanjen.

Dari fenomena di atas maka peneliti ingin menelititentang bagaimana strategi pelaksanaan, model pelaksanaan, manajemen pelaksanaan kantin jujur di SDN Panggungrejo04 Kepanjen.

\section{a. Pengertian Kantin Jujur}

Kantin Jujur sebagai salah satu program pemerintah dalam hal menanamkan sifat kejujuran bagi generasi muda memang telah mendapatkan respon positif dari masyarakat. Kini, masyarakat luas sependapat bahwa pengadaan "kantin jujur" di tengah-tengah mereka memang perlu adanya. Kantin jujur adalah kantin yang menjual makanan kecil dan minuman. Kantin jujur tidak memiliki penjual dan tidak dijaga. makanan atau minuman dipajang dalam kantin. Dalam kantin tersedia kotak uang, yang berguna menampung pembayaran dari yang membeli makanan atau minuman. Bila ada kembalian, pengunjung atau pegawai mengambil dan menghitung sendiri uang kembalian dari dalam kotak tersebut. Di kantin ini, kesadaran pengunjung atau pegawai sangat dituntut untuk berbelanja dengan membayar dan mengambil uang kembalian jika memang berlebih, tanpa harus diawasi oleh pegawai kantin. Salah satu motto yang ditanamkan dikantin ini adalah Allah melihat malaikat mencatat.

\section{b. Pengertian Pendidikan Karakter}

Kata karakter berasal dari kata $\mathrm{Yu}-$ nani, Charassein, yang berarti "mengukir" sehingga terbentuk sebuah pola. Mempunyai akhlak mulia adalah tidak secara otomatis dimiliki oleh setiap manusia begitu ia dilahirkan, tetapi memerlukan proses panjang melalui pengasuhan dan pendidikan (proses pengukiran). Dalam 
istilah bahasa Arab karakter ini mirip dengan akhlak (akar kata khuluk), yaitu "tabiat atau kebiasaan" melakukan hal yang baik. Al Ghazali menggambarkan bahwa akhlak adalah tingkah laku seseorang yang berasal dari hati yang baik (Samani \& Hariyanto, 2012).

Pendidikan karakter juga dapat diartikan sebagai pendidikan yang mengembangkan karakter yang mulia (good character) dari peserta didik dengan mempraktikkan dan mengajarkan nilai-nilai moral dan pengambilan keputusan yang beradab dalam hubungan dengan sesama manusia maupun dalam hubungannya dengan Tuhannya. Definisi ini dikembangkan dari definisi yang dimuat dalam Funderstanding (2006). Departemen Pendidikan Amerika Serikat mendefisinikan pendidikan karakter sebagai berikut: "Pendidikan karakter mengajarkan kebiasaan berpikir dan kebiasaan berbuat yang dapat membantu orang-orang hidup dan bekerja bersama sebagai keluarga, sahabat, tetangga, masyarakat, dan bangsa." Menjelaskan pengertian tersebut dalam brosur pendidikan karakter (Character Education Brochure) dinyatakan bahwa: "Pendidikan karakter adalah suatu proses pembelajaran yang memberdayakan siswa dan orang dewasa di dalam komunitas sekolah untuk memahami, peduli tentang, dan berbuat berlandaskan nilai-nilai etik seperti respek, keadilan, kebajikan warga (civic virtue) dan kewarganegaraan (citizenship), dan bertanggung jawab terhadap diri sendiri maupun kepada orang lain (Samani, 2012: 43-44).

Pendidikan karakter menurut Ratna Megawangi (2004:95), "sebuah usaha untuk mendidik anak-anak agar dapat mengambil keputusan dengan bijak dan mempraktikannya dalam kehidupan sehari-hari, sehingga mereka dapat memberikan kontribusi yang positif kepada lingkungannya." Definisi lainnya dike- mukakan oleh Fakry Gaffar (2010:1): "sebuah proses transformasi nilai-nilai kehidupan untuk ditumbuh kembangkan dalam kepribadian seseorang sehingga menjadi satu alam perilaku kehidupan orang itu." Dalam definisi tersebut ada ide pikiran penting, yaitu: 1) proses transformasi nilai-nilai, 2) ditumbuh kembangkan dalam kepribadian, dan 3) menjadi satu dalam perilaku. (Kesuma, 2012: 5)

Tujuan jangka panjang untuk membentuk generasi penerus yang bersih dan jujur, karena kantin jujur ini menjadi ajang pembelajaran bagi generasi muda tentang pentingnya kejujuran terhadap diri sendiri, lingkungan, hingga bangsa dan negara. Kantin jujur sebagai tempat untuk melatih kejujuran, sehingga tugas Komisi Pemberantasan Korupsi (KPK) dalam pelaksanaannya dapat melakukan pendidikan antikorupsi sedini mungkin, melalui kantin jujur di sekolah. Kejujuran merupakan salah satu bentuk kegiatan dalam pendidikan antikorupsi. (Kurniawan dkk., 2009)

\section{c. Peran Guru dalam Pendidikan Karakter di Sekolah}

Peran seorang guru tidak hanya mengajar, tetapi juga mendidik anak, sehingga anak tidak hanya memiliki kecerdasan kogntif, tetapi juga memiliki karakter yang baik. Guru di sekolah tidak hanya mengajar (transfer of knowledge) melainkan juga mendidik (transfer of attitude) sehingga dengan demikian guru harus memberikan bimbingan mengenai nilai-nilai positif yang berlaku di dalam kehidupan (Suwati, 2008 : 19).

Peran guru di atas yang nantinya dapat mewujudkan strategi tujuan dari pendidikan, yaitu untuk berkembangnya potensi peserta didik agar menjadi manusia yang beriman dan bertaqwa kepada Tuhan Yang Maha Esa, berakhlak mulia, 
sehat, berilmu, cakap, kreatif, mandiri, dan menjadi warga negara yang demokratis serta bertanggung jawab (Arifin : 2003, 37).

Untuk mewujudkan tujuan pendidikan tersebut berbagai inovasi pendidikan sangat dibutuhkan. Guru sebagai pembelajar hendaknya melakukan berbagai inovasi yang tidak hanya meningkatkan kualitas di bidang akademik semata, tetapi juga pembinaan akhlak pun harus mendapat perhatian. Salah satunya yang dapat dilakukan oleh guru yaitu dengan membuat kantin kejujuran. Guru sebagai pembelajar berperan menjelaskan sesuatu menjadi jelas bagi peserta didik dan berusaha lebih terampil dalam memecahkan masalah. Budi Yuwono dalam bukunya yang berjudul "SQ Reformation" menyebutkan bahwa karakter individu yang jujur yaitu tabiatnya selalu bersikap objektif sesuai dengan kebenaran yang diketahuinya dan tabiatnya menunjukkan individu yang mempunyai prinsip dan integritas sehingga dipercaya oleh banyak pihak (Yuwono, $2010: 212$ ).

\section{d. Model Penanaman Karakter di Sekolah}

Penanaman nilai-nilai kejujuran melalui kantin jujur merupakan model pembelajaran simulasi sosial. Model pembelajaran ini menganggap peserta didik (pembelajar) sebagai suatu sistem yang dapat mengendalikan umpan balik sendiri (self regulated feadback). Sistem kendali umpan balik ini mempunyai tiga fungsi, antara lain : 1) Menghasilkan tindakan sistem terhadap target yang diinginkan (untuk mencapai tujuan tertentu yang diinginkan). 2) Membandingkan dampak dari tindakannya tersebut, apakah sesuai atau tidak dengan rencana yang seharusnya (mendeteksi kesalahan). 3) Memanfaatkan kesalahan untuk menga- rahkan kembali ke arah / jalur yang seharusnya (Uno: 2010, 28).

Dengan demikian dapat dikatakan bahwa kantin jujur merupakan suatu sistem kontrol yang dapat mengarahkan tindakan peserta didik dan memperbaiki tindakannya dengan mendasarkan tindakannya pada umpan balik. Jadi pada kantin kejujuran peserta didik sebagai simuulator akan menjadi pelaku koreksi diri (self corrective behavior) khususnya koreksi diri dalam hal kejujuran mereka ketika membeli sesuatu di kantin kejujuran.

Hamzah B. Uno mengatakan bahwa ada empat langkah dalam penerapan model pembelajaran simulasi sosial yang dapat dilakukan oleh guru, antara lain: 1) Menyiapkan peserta didik menjadi pemeran dalam simulasi. 2) Guru menyusun skenario dengan memperkenalkan peserta didik terhadap aturan, peran, prosedur, tujuan, dan lain-lain. 3) Pelaksanaan dari simulasi itu sendiri. 4) Debriefing, yaitu guru mendiskusikan tentang hasil simulasi (Uno, 30).

Dari penjelasan di atas, maka ada empat hal yang dilakukan oleh guru dalam menjadikan kantin kejujuran sebagai sebuah simulasi, antara lain: 1) Guru menyiapkan peserta didik sebagai pembeli pada kantin kejujuran. 2) Guru menyusun skenario dengan memperkenalkan peserta didik terhadap aturan, peran, prosedur, dan tujuan dari kantin kejujuran. 3) Guru melaksanakan simulasi dalam bentuk kantin kejujuran. 4) Guru mendiskusikan hasil simulasi dalam bentuk kantin kejujuran kepada peserta didik. Model pembelajaran simulasi sosial bagi peserta didik lebih banyak berperan sebagai dirinya sendiri saat saat melakukan suatu kegiatan atau tugas yang benar-benar akan dilakukannya (Firdaus: 2010, 48).

Sedangkan Endang Mulyatiningsih, 2012 mengutarakan model pendidik- 
an pada anak-anak bertujuan untuk membentuk karakter. Anak-anak masih dalam masa bermain, oleh sebab itu model pendidikan karakter yang efektif disampaikan melalui kegiatan bermain peran, bercerita, kantin kejujuran dan lainnya.Salah satu model yang dapat dikembangkan untuk penanaman karakter dalah melalui pembelajaran kewirausahaan. Kewirausahaan (entrepreneurship) pada hakikatnya adalah sifat, ciri, dan watak seseorang yang memiliki kemauan dalam mewujudkan gagasan inovatif ke dalam dunia nyata secara kreatif (Suryana, 2006: 14). Pembelajaran kewirausahaan yang dikembangkan di sekolah dasar berbentuk keterlibatan siswa dalam pengelolaan kantin jujur.Dengan adanya jadwal piket tiap kelas ini diharapkan mampu membentuk karakter siswa yang mandiri, tangguh, percayadiri, pekerja keras yang mampu bersaing di era global. Nilai-nilai pokok kewirausahaan yang diharapkan dapat diinternaslisasi oleh siswa ada 6 (enam) nilai pokok yaitu : mandiri, kreatif pengambil resiko, kepemimpinan, orientasi pada tindakan dan kerja keras(AkhmadSudrajat, 2011).

\section{e. Implementasi Kejujuran di Sekolah Dasar}

Guru adalah faktor kunci dalam keberhasilan implementasi kurikulum. Guru yang luar biasa sering dapat menciptakan kualitas sumber daya yang miskin dengan kinerjanya yang optimal. Tapi kenyataannya banyak guru yang belum cukup terlatih untuk dapat membuat bahan atau media pembelajaran yang efektif. Di setiap lembaga, kemampuan guru dapat bervariasi sesuai dengan berbagaidimensi, seperti kemahiran bahasa, pengalaman mengajar,keterampilan keahlian, pelatihan dan kualifikasi, semangat danmotivasi, gaya mengajar, keyakinan dan prinsip-prinsip (Richard : 2002, 99). Dimensi-dimensi kemampuan guru di atas mempunyai konstribusi terhadap peran guru dalam menanamkan nilai-nilai kejujuran peserta didik. Peranperan tersebut antara lain : Guru menyediakan kantin jujur di sekolah bagi peserta didik.

Dilihat dari tujuan kantin sekolah di atas, maka kantin sekolah dapat berfungsi untuk : 1) membantupertumbuhan dan kesehatan peserta didik dengan jalan menyediakan makanan yang sehat, bergizi, dan praktis ; 2) mendorong peserta didik untuk memilih makanan yang cukupdan seimbang ; 3) untuk memberikan pelajaran sosial kepada peserta didik ; 4) memperlihatkan kepada peserta didik bahwa faktor emosi berpengaruh pada kesehatan seseorang ; 5) memberikan bantuan dalam mengajarkan ilmu gizi secaranyata ; 6) mengajarkan penggunaan tata krama yang benar dan sesuai dengan yang berlaku di masyarakat ; 7) sebagai tempat untuk ber berdiskusi tentang pelajaran-pelajaran di sekolah, dan tempat menunggu apabila ada jam kosong.

Terkait dengan bentuk pelayanan kantin sekolah, terdapat 3 (tiga) alternatif bentuk layanan, yaitu : 1) Self service system. Sistem pelayanan di mana pembeli melayani dirinya sendiri makanan yang diingini ; 2) Wait service system Sistem pelayanan di mana pembeli menunggu dilayani oleh petugas kantin sesuai dengan pesanan ; 3) Tray service system. Sistem pelayanan di mana pembeli dilayani petugas kantin, dan penyajian makanannya dengan menggunakan baki atau nampan (Sudrajat : 2011). Kantin jujur merupakan kantin sekolah yang menggunakan self system service. Kantin jujur dapat memberikan peluang untuk mengembangkan tingkah laku dan kebiasaan positif di kalangan peserta didik. Beberapa indikator dalam penye- 
diaan kantin jujur tersebut adalah transaksi jual-beli yang diterapkan adalah self service, artinya pembeli melayani sendiri dalam proses pembelian barang yang dibutuhkan. Pembeli secara leluasa mengambil kebutuhan yang hendak dibelinya sehingga dalam penerapan kantin jujur ini tidak ada penjual yang menjaga atau mengawasi secara langsung proses transaksi jual-belinya. Sedangkan mengenai harga sebuah produk hanya ditempel label harga sehingga pembeli dapat mengetahuinya.

Kemudian dari segi penataan ruangan harus diatur sedemikian menarik, menu yang disediakan bervariasi, harga disesuaikan dengan kondisi ekonomi peserta didik. Menu-menu yang disediakan dapat disajikan di atas meja yang telah tertata dan juga dapat disajikan di dalam etalase. Penyediaan kantin jujur di sekolah harus ditopang oleh manajemen yang efektif dan efisien. Artinya, pelaksanaan program kantin jujur mulai dari tahap perencanaan, pengorganisasian, pelaksanaan, hingga evaluasi harus dilakukan dan diarahkan kepada kemajuan dan hasil yang optimal. Proses pembukuan keuangan maupun laporannya juga harus cermat dan teliti. Tidak kalah pentingnya, penerapan kantin jujur disekolah dilaksanakan atau beroperasi di jam-jam tertentu sehingga tidak mengganggu kepentingan sekolah yang lainnya. Manfaat yang dapat diperoleh dari kantin jujur antara lain :

1) Bagi peserta didik: dapat melatih kejujuran dan sikap tanggung jawab yang diberikan serta sikap kemandirian.

2) Bagi guru: sebagai sarana mengaplikasikan nilai-nilai kejujuran yang telah diajarkan di dalam kelas.

3) Bagi sekolah: terbentuknya perilaku jujur di lingkungan sekolah.
Sementara itu, hasil yang dapat diharapkan dari pelaksanaan kantin jujur antara lain:

1) Efisiensi system pengajaran pendidikan anti korupsi.

2) Persepsi negatif dari peserta didik terhadap perilaku korupsi dengan harapan peserta didik tidak melakukan korupsi ketika berada di tengah lingkungan masyarakat di masa depan.

Selain menjelaskan manfaat yang dapat diperoleh dari kantin jujur, guru juga harus menjelaskan kerugian yang dapat diderita oleh kantin jujur.Kerugian tersebut yaitukantin jujur bisa bangkrut jika peserta didik membeli makanan dengan berbuat bohong, curang, dan tidak jujur. Guru menanyakan kepada peserta didik apa yang harus dilakukan oleh mereka agar kemanfaatan kantin jujur bisa diraih. Peran ini merupakan peran reflektif yang dimainkan oleh guru. Tentu saja pemberian pertanyaan didasarkan pada kondisi kognitif atau pengetahuan peserta didik.

Guru memberikan motivasi kepada peserta didik untuk membelijajan di kantin jujur.Motivasi dapat memberikan semangat yang luar biasa terhadap seseorang untuk berperilaku dan dapat memberikanarah dalam berperilaku. Motivasi pada dasarnya merupakan keinginan (wants) yang ingin dipenuhi (dipuaskan), maka ia timbul jika ada rangsangan, baik karena adanya kebutuhan (needs) maupun minat (interest) terhadap sesuatu (Asra: 2007, 236).

Dalam usaha untuk mencapai tujuan dan manfaat serta hasil yang diharapkan dari pelaksanaan kantin jujur, perubahan tingkah laku peserta didik diharapkan terjadi. Karena itu guru bertugas memotivasi peserta didik untuk membeli jajan di kantin jujur demi tercapainya tujuan yang diharapkan serta memperoleh tujuan, manfaat, dan hasil yang diinginkan (Soemanto: 2006, 213). Guru mem- 
berikan pemahaman dan keyakinan kepada peserta didik bahwa segala perbuatan mereka dicatat oleh malaikat. Jika ada peserta didikyang membeli dengan curang maka mereka akan mendapatkan catatan dosa dari malaikat. Dengan pemahaman dan keyakinan tersebut diharapkan peserta didik melakukan transaksi jual-beli di kantin kejujuran dengan jujur, tidak curang atau berbohong.

Kemudian agar tujuan, manfaat, dan hasil yang diharapkan dari kantin jujur dapat dicapai, maka para pengelola kantin kejujuran hendaknya dituntut untuk kreatif dalam menyiasati pangsa pasar, harga barang yang dijual di kantin kejujuran hendaknya lebih rendah dari harga pasaran sehingga dapat lebih menarik peserta didik. Selain itu, harus dijalin kerjasama yang baik dengan semua elemen sekolah seperti guru, karyawan, Organisasi Siswa Intra Sekolah (OSIS), dan juga komite sekolah. Tujuan dari dijalinnya kerjasama tersebut adalah apabila terjadi hal-hal yang diinginkan, pihak-pihak yang dilibatkan itu bisa bekerja sama dan cepat dalam mengatasinya. Kemudian untuk mengurangi resiko adanya peserta didik yang tidak membayar, dapat diminimalisir dengan memasang CCTV secara tersembunyi di kantin jujur dan guru dapat memberikan sanksi atau pun hukuman bagi peserta didik yang tidak membayar sebagai sebuah pembelajaran.

\section{METODE PENELITIAN}

Penelitian kualitatif merupakan sebuah pendekatan penelitian yang diselenggarakan dalam setting alamiah dan memerankan peneliti sebagai instrumen pengumpul data. Bogdan dan Taylor (dalam Moleong, 2005: 4) mengemukakan bahwa "metodologi kualitatif merupakan prosedur penelitian yang menghasilkan data deskriptif berupa kata-kata tertulis maupun lisan dari orang-orang dan perilaku yang diamati”. Berdasarkan kedua pengertian tersebut dapat disimpulkan bahwa penelitian kualitatif merupakan metode penelitian yang menghasilkan penemuan yang tidak dapat dicapai dengan menggunakan prosedur statistic atau dengan cara pengukuran data yang terkumpul di lapangan. Oleh karena itu, peneliti harus memiliki bekal teori dan wawasan yang luas. Sehingga peneliti harus bisa bertanya, menganalisis, dan mengkonstruksi objek yang diteliti.

Berkaitan dengan tujuan penelitian dan uraian di atas, peneliti menggunakan jenis penelitian studi kasus sehingga penela'ahan terhadap fokus penelitian dapat dilakukan secara intensif, mendalam, detail, dan komprehensif (Faisal, 20 01: 22). Penelitian ini dilakukan di Sekolah Dasar Negeri (SDN) Panggungrejo 04 Kepanjen yang terletak di jalan Panji No. 3, Desa Panggungrejo, Kecamatan Kepanjen, Kab/Kota Malang, Propinsi Jawa Timur, Nomor Telp/HP: (0341) 399007.

Pelaksanaan penelitian ini dimulai dengan studi pendahuluan atau observasi pada bulan April 2013. Kehadiran peneliti dilokasi penelitian sangat diperlukan guna menjawab fokus penelitian, pengumpulan data dan menciptakan hubungan yang baik dengan subjek penelitian. Berdasarkan studi dokumentasi yang telah dilakukan oleh peneliti.

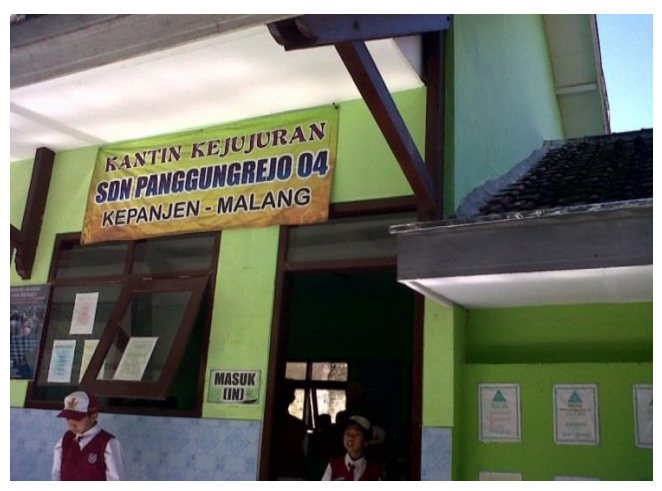


Gambar 3.1 Kantin Kejujuran SDN Panggungrejo 04 Kepanjen-Malang (Tampak dari depan). Sumber: Dokumentasi peneliti, 2 April 2013.

Teknik yang digunakan dalam menentukan informan utama yakni dengan menggunakan teknik snowball sampling. Informan utama dalam penelitian ini yakni kepala sekolah. Hal ini dikarenakan kepala sekolah dianggap sebagai subjek yang memahami fokus untuk menjawab masalah dalam penelitian. Informan utama dalam penelitian ini yakni bapak Radi Sucipto, M.Pd selaku Kepala Sekolah SDN Panggungrejo 04 Kepanjen dan informan tambahan yakni bapak/ibu guru SDN Panggungrejo 04 Kepanjen selaku pelaksana harian dari kegiatan pelaksana kantin jujur.

Ada tiga teknik dasar yang digunakan oleh peneliti dalam pengumpulan data yaitu, teknik wawancara, teknik observasi, dan teknik analisis dokumentasi. Analisis data dalam penelitian ini menggunakan analisis terjalin. Sumber data utama yaitu hasil wawancara dengan kepala sekolah dan guru selaku pelaksana pelaksana dan pengelola kantin jujur di SDN Panggungrejo 04 Kepanjen Malang. Ada tiga siklus dalam analisis data yaitu; (a)reduksi data, (b) penyajian data, dan (c) penarikan kesimpulan.

Tahap penelitian yang akan dilakukan adalah sebagai berikut: Pertama: tahap pendahuluan yaitu studi pendahulupendahuluan (pra survey), Kedua: pengajuan usulan penelitian, Ketiga: tahap pelaksanaan, Keempat: tahap penyusunan laporan penelitian, Penelitian ini pada garis besarnya dapat dijabarkan menjadi tiga tahap, yaitu tahap persiapan dimana peneliti menyusun kerangka penelitian, tahap pelaksanaan dimana peneliti melakukan observasi dan wawancara, dan terakhir tahap penyelesaian yakni peneliti mengolah dan menganalisis data untuk kemudian menyusun laporan hasil penelitian.
Supaya hasil penelitian ini dapat dipertanggungjawabkan, maka diperlukan kegiatan pengecekan keabsahan data, yaitu dengan cara perpanjangan keikutsertaan, ketekunan pengamatan, dan trianggulasi. Dalam penelitian kualitatif, keabsahan data merupakan usaha untuk meningkatkan derajat kepercayaan data (Moleong, 2001: 107). Untuk menjaga keabsahan data peneliti mengikuti empat kriteria yang disarankan Nasution dan Moleong, yaitu kredibilitas atau derajat kepercayaan, transferabilitas atau keteralihan, dependibilitas atau kebergantungan dan konfirmabilitas atau kepastian.

\section{B. HASIL YANG DICAPAI}

Berdasarkan penelitian yang sudah dilaksanakan ada beberapa hasil yang sudah didapatkan. Hasil tersebut meliputi

a) Strategi Pelaksanaan Pendidikan Karakter Siswa Di SDN Panggungrejo 04 Kepanjen

Ada beberapa kegiatan yang menjadi strategi pelaksanaan pendidikan karakter siswa di SDN Panggungrejo 04 Kepanjen, sebagaimana telah diungkapkan oleh kepala sekolah SDN Panggungrejo 04 Kepanjen Malang dari hasil wawancara sebagai berikut. Telah dilaksanakan beberapa program kegiatan diantaranya kegiatan siswa penggerak disiplin, yaitu siswa yang disiplin bias mengajak teman kelasnya atau kelas yang lain untuk disiplin dengan cara pelatihan, bimbingan dan perhatian guru pada siswa yang terpilih sebagai siswa penggerak disiplin pada tingkatan kelas tersebut. Kemudian ada lagi program pendidikan lingkungan hidup, program pemilahan sampah yang dilakukan pada tiap hari Jum'at, UKS atau unit kesehatan sekolah untuk mengaplikasikan kesehatan warga sekolah, dan kantin kejujuran guna melatih kejujuran dan tanggung jawab sebagai siswa yang kreatif. 
Untuk menanamkan strategi siswa yang mandiri, maka anak-anak di sekolah diikutkan dalam kegiatan kantin jujur sebagai wahana belajar siswa di kantin, supaya mereka terlatih skill enterpreneurship, pribadi yang ulet, terampil, jujur, dan kelak menjadi manusia yang tanggung jawab sejak dini. Keterlibatan siswa dalam program kantin jujur adalah mulai tahap persiapan, pelaksanaan dan pencatatan laporan atau hasil evaluasi. Membantu mempersiapkan menu makanan dan minuman jajanan yang dijual di meja masing-masing kelas, kemudian mencatat jumlah barang jajanan, kemudian tahap pelaksanaan mereka sudah menyiapkan kaleng uang recehan untuk kembalian dan kaleng uang pembayaran. Diakhir mereka mencatat menu di buku catatan tiap kelasnya.

Hal ini diungkapkan oleh koordinator kantin, "pada awalnya anak-anak masih kesulitan untuk jujur, akan tetapi dengan strategi pelibatan siswa dalam proses piket di kantin maka laba atau keuntungan sekolah bisa menutupi siswa yang masih belum jujur karena mereka belum mengerti uang, khususnya kelas 1 yang masih proses mengenal nominal uang rupiah.

b). Model Pelaksanaan Kantin Jujur di SDN Panggungrejo 04 Kepanjen

Penanaman nilai-nilai kejujuran melalui kantin jujur merupakan model pembelajaran simulasi sosial. Hal ini terlihat dari tujuan adanya kantin jujur di sekolah ini sebagai tempat untuk siswa belajar kreatif dan enterpreneurship. Dengan menanamkan sikap jujur pada siswa, supaya siswa bisa membiasakan kejujuran dimanapun dan kapanpun mereka berada.

Dari hasil pengamatan peneliti model penjualan di kantin adalah;

1. Makanan dan minuman dari penyetor dikumpulkan di kantin,
2. Kemudian petugas kantin dibantu para piket kantin dari perwakilan siswa kekelas lima menata menu makanan dan minuman yang sama pada meja tiap kelas serta mencatatnya.

3. Menyiapkan kaleng uang kembalian dan kaleng uang pembayaran pada tiap meja kelas.

Ketika waktu istirahat mulai maka anak-anak mengambil menu makanan dan minuman di meja kelasnya masingmasing dan membayar sesuai harga makanan dan minuman yang diambil. Dan jika ada kembalian maka mereka ambil di kaleng kembalian.

Sebagai berikut model meja penjualan di kantin;

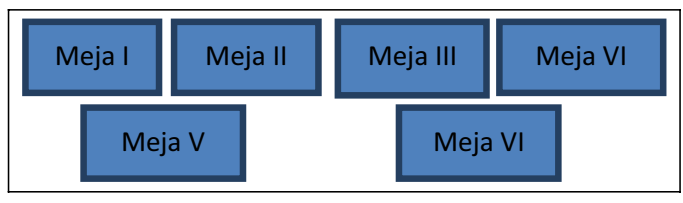

Gambar 5.1 model penjualan di kantin (meja 1VI melayani varian makanan dan minuman kelas 1 - kelas VI).

c. Manajemen Pelaksanaan Kantin Jujur Di SDN Panggungrejo $04 \mathrm{Ke}-$ panjen

Pengelolaan kantin jujur di SDN Panggungrejo 04 dilakukan dengan sistem terstruktur. Ada koordinator pengelolaan kantin jujur, ada petugas kantin sebagai pengelola keuangan dari pemasok makanan dan minuman yang ada di kantin, dan pelibatan siswa sebagai petugas piket dalam membantu dalam persiapan dan pembuatan laporan dari awal sampai akhir tiap kelas. Sedangkan jika ada sanksi maka peringatan atau hukuman akan diberikan secara langsung pada guru wali kelas dan komite selaku perwakilan dari walimurid di sekolah ter sebut. Dari penjelasan ini dapat ditarik kesimpulan bahwa manajemen pelaksanaan kantin kejujuran dilakukan secara 
terkoordinir dan berorientasi tujuan, yaitu memperbaiki perilaku anak yang kurang jujur.

\section{KESIMPULAN DAN SARAN}

Dalam rangka peningkatan pendidikan karakter di tingkat sekolah dasar SDN Panggungrejo 4 telah melaksanakan beberapa program salah satuya kantin jujur. Harapan untuk mewujudkan siswa yang kreatif maka dalam pelaksanaan perlu adanya strategi, model dan manajemen kantin jujur.

Selain itu, juga dalam meningkatkan karakter siswa sekolah dasar dalam pelaksanaan kantin jujur juga didukung oleh program kawan asah, asih. Maksudnya asah; untuk membentuk kesetiakawanan, solidaritas yang tinggi antar siswa, guna mengantisipasi adanya kesenjangan sosial antar varian siswa. Dan asih; adalah sebagai makhluk sosial yang senantiasa membutuhkan dalam hidupnya maka harus dijunjung tinggi sifat pengasih dan penyayang. Dalam pengelolaan atau manajemen kantin jujur juga dibantu oleh kepala sekolah dan para guru dengan adanya sistem kontrol setiap bulan mulai dari persiapan, pelaksanaan, dan pelaporan. Harapannya anak senantiasa mendapatkan bimbingan dan pengarahan untuk berkembang sesuai potensinya untuk menjadi manusia yang seutuhnya.

Hasil penelitian ini masih sangat memungkinkan untuk dikembangkan kembali oleh peneliti, selayaknya manuia yang terus mau belajar sehingga tidak tertinggal oleh kemajuan Iptek. Kami sangat berterima kasih atas masukan dan saran untuk kemajuan perbaikan penelitian ini selanjutnya.

\section{DAFTAR PUSTAKA}

Andayati, Dina. 2012. Kantin Kejujuran Berbasis Teknologi Informasi. Jur- nal Teknologi Technoscientia ISSN: 1979-8415 Vol. 4 No. 2 Februari 2012, hlm. 128.

Akhmad Sudrajat, Tentang Kantin Kejujuran, diunduh pada tanggal 23 Oktober 2011, pukul 15.45 WIB di (http://akhmadsudrajat.wordpress.c om/2010/06/03/tentang-kantinsekolah).

Arifin, Anwar. 2003. Memahami Paradigma Baru Pendidikan Nasional dalam Undang-Undang. SISDIKNAS. Jakarta : Depag RI.

Asra, dan Sumiati. 2007. Metode Pembelajaran. Bandung: Wacana Prima.

Bungin, Burhan. 2007. Penelitian Kualitatif. Jakarta: Kencana Prenada Media Group.

EndahSulistyowati. 2012. Implementasi ImplementasiKurikulumPendidika nKarakter, Yogyakarta: PT. Citra AjiParama.

Faisal, Sanapiah. 2006. Penelitian Kualitatif; Dasar-dasar dan Aplikasi. Malang: YayasanAsahAsihAsuh.

Kasuma, Dharma. Dkk. 2012, Pendidikan Karakter (Kajian Teori dan Praktik di Sekolah), Bandung: PT. Remaja Rosdakarya.

Moleong, Lexy J. 2001. Metodologi Penelitian Kualitatif, Bandung: PT Remaja Rosdakarya.

Suryana. 2006. Kewirausahaan. Pedoman praktis: kiatdan proses menusukses. Jakarta: SalembaEmpat.

Undang-undang Republik Indonesia No. 20 Tahun 2003. Sistem Pendidikan Nasional. Bandung: Citra Umbara.

Uno, Hamzah B. 2010. Model Pembelajaran: Menciptakan Proses Belajar Mengajar yang Kreatif dan Efektif. Jakarta :BumiAksara.

Muchlas Samani dan Hariyanto, 2012, Konsep dan Model Pendidikan Karakter, Bandung: PT. Remaja Rosdakarya.

Suwati. 2008. Sekolah Bukan Untuk 
Yulianti, Kajian Kantin Jujur dalam Rangka Peningkatan Pendidikan Karakter di Tingkat

Sekolah Dasar Untuk Mewujudkan Siswa yang Kreatif Studi Kasus di SD Panggung Rejo

04 Kepanjen

Mencari Pekerjaan. Jakarta: Pustaka Grafika.

Yuwono, Budi. 2010. SQ Reformation. Jakarta: Gramedia. 